\title{
PENERAPAN MODEL PEMBELAJARAN THINK PAIR SHARE UNTUK MENINGKATKAN HASIL BELAJAR MATEMATIKA SISWA KELAS 3 SDN 009 RAMBAH SAMO
}

\author{
Suprapti \\ SDN 009 Rambah Samo \\ supraptiirsyad68@gmail.com
}

\begin{abstract}
This research background was the low learning outcomes of students in grade 3 at SDN 009 Rambah Samo. The purpose of this study is to improve student mathematics learning outcomes through the application of Think Pair Share (TPS) learning. The type of research conducted is classroom action research. The study implemented in two cycles, with three meetings in each period. Classroom action research procedures carried out include planning, implementing, observing, and reflecting. The instrument used was a test of learning outcomes and an observation sheet of teacher and student activities. The results showed that the average student learning outcomes increased from 52.95 in the initial data to 69.86 in the first cycle with a percentage increase of $31.94 \%$ and 84.17 in the second cycle with an increase from cycle 1 of $20,7 \%$. Individual completeness obtained from the initial data up to cycle 2 was $43.47 \%, 65.21 \%$, and $78.26 \%$, respectively. So it can be concluded that the application of the TPS learning model can improve mathematics learning outcomes of students in grade 3 at SDN 009 Rambah Samo.
\end{abstract}

Keywords: Think Pair Share, Cooperative learning, learning outcomes, mathematics.

ABSTRAK Penelitian ini dilatar belakangi oleh rendahnya hasil belajar matematika siswa kelas 3 SDN 009 Rambah Samo. Tujuan penelitian ini yaitu untuk meningkatkan hasil belajar matematika siswa melalui penerapan pembelajaran Think Pair Share (TPS). Adapun jenis penelitian yang dilakukan yaitu penelitian tindakan kelas. Penelitian dilaksanakan sebanyak dua siklus, dengan tiga kali pertemuan di setiap siklusnya. Prosedur penelitian tindakan kelas yang dilaksanakan meliputi perencanaan, pelaksanaan, pengamatan, dan refleksi. Instrumen yang digunakan berupa tes hasil belajar dan lembar pengamatan aktivitas guru dan siswa. Hasil penelitian menunjukkan bahwa rata-rata hasil belajar siswa mengalami peningkatan yaitu dari 52,95 pada data awal menjadi 69,86 pada siklus I dengan persentase peningkatan sebesar 31,94\% dan 84,17 pada siklus II dengan peningkatan dari siklus 1 sebesar $20,7 \%$. Ketuntasan individu yang diperoleh dari data awal hingga siklus 2 berturut-turut adalah $43,47 \%, 65,21 \%$, dan $78,26 \%$. Sehingga dapat disimpulkan bahwa penerapan model pembelajaran TPS dapat meningkatkan hasil belajar matematika siswa kelas 3 SDN 009 Rambah Samo.

Kata-kata Kunci: Pembelajaran Think Pair Share, Pembelajaran Kooperatif, hasil belajar, matematika 


\section{PENDAHULUAN}

Pendidikan memiliki peranan besar dalam membentuk manusia Indonesia seutuhnya. Penyelengaraan pendidikan baik formal maupun non formal harus disesuaikan dengan tuntutan pembangunan dan kemajuan IImu Pengetahuan dan Teknologi (IPTEK). Tolak ukur keberhasilan suatu pendidikan dapat terlihat dari tercapai atau tidaknya tujuan pendidikan tersebut. Upaya pencapaian tujuan pendidikan butuh kerjasama dari semua pihak, bukan hanya guru. Pendidikan di Indonesia terdiri dari empat jenjang yaitu pendidikan anak usia dini, pendidikan dasar, pendidikan menengah dan pendidikan tinggi. Matematika merupakan salah satu mata pelajaran yang ada pada semua jenjang tersebut.

Mata pelajaran matematika mempunyai peran aktif dalam berbagai disiplin ilmu serta dapat memajukan daya fikir manusia. Selain itu, matematika diberikan dari tingkat sekolah dasar bertujuan untuk membekali siswa dengan kemampuan berfikir logis, anaslisis, sistematis, kreatif, kritis dan kemampuan untuk bekerja sama. Untuk itu guru harus memahami hakikat pembelajaran matematika di sekolah dasar agar ketika merancang sebuah proses pembelajaran yang baik bagi siswa, dapat menjadi pembelajaran yang aktif, efektif dan tepat maka di perlukan penggunaan metode, pendekatan dan media yang sesuai. Sehingga diharapkan siswa termotivasi dan aktif dalam belajar matematika.

Saat ini, pembelajaran di sekolah dasar menggunakan tematik, yaitu pembelajaran tepadu yang menggunakan tema untuk mengaitkan beberapa mata pelajaran sehingga dapat memberikan pengalaman bermakna kepada siswa. Hal ini juga dilaksanakan di SDN 009 Rambah Samo. Dalam hal ini, penelitian dilakukan pada sub tema wujud benda yang berkaitan dengan matematika. Dari hasil refleksi terhadap hasil belajar siswa, terdapat permasalahan berkaitan dengan rendahnya hasil belajar siswa tersebut. Masih banyak siswa yang menganggap bahwa mata pelajaran matematika sulit untuk dipahami. Selain itu, dalam proses pembelajaran siswa kurang aktif. Pembelajaran yang terjadi masih satu arah. Guru memberi kesempatan kepada siswa untuk bertanya, namun siswa hanya diam. Disamping itu guru juga meminta siswa untuk menuliskan jawaban di papan tulis, mereka masih malu-malu dan yang sering tampil kedepan hanya siswa yang pintar saja. Selanjutnya siswa juga jarang bekerja sama dalam kelompok, hal ini diduga salah satu penyebab kurangnya interaksi di kelas.

Dengan adanya kondisi tersebut, maka guru perlu mengelola proses pembelajaran dengan baik. Hal ini sejalan dengan pendapat Yamin dan Ansari (2009) bahwa pengelolaan proses pembelajaran merupakan salah satu komponen yang mempengaruhi keberhasilan pembelajaran. Salah satu caranya yaitu dengan menerapkan model pembelajaran yang tepat dan sesuai, yaitu pembelajaran Think Pair Share (TPS). TPS merupakan pembelajaran kooperatif yang pertama kali diperkenalkan oleh Frang Lyman dan koleganya di Universitas Maryland. Pelaksanaannya TPS meliputi tiga komponen diantaranya, berpikir sendiri, berpasangan dan berbagi dengan kelompok lainnya (Bamiro, 2015; Raba, 2017; Kwok \& LaU, 2015). Model pembelajaran TPS dimulai dengan guru memberikan permasalahan matematika kepada siswa, kemudian siswa diberikan waktu untuk 
berpikir secara individu menyelesaikan permasalahan tersebut, selanjutnya siswa diminta untuk diskusi berpasangan terkait pemecahan masalah yang diperoleh pada tahap think, dan terakhir siswa diarahkan untuk berdiskusi secara klasikal (diskusi pleno) terkait hasil pada tahap pair.

TPS memberikan kesempatan kepada siswa untuk berpartisipasi kepada siswa lainnya. Keunggulan model ini yaitu optimalisasi partisipasi siswa dalam pembelajaran matematika. Dalam pembelajaran TPS, siswa dituntut untuk bekerja sama dan saling menghargai pendapat orang lain. Selanjutnya, salah satu aspek positif dari TPS yaitu dengan memberikan waktu bagi siswa (think) untuk menyelesaikan pertanyaan atau permasalahan yang diberikan, ini dapat memberikan dampak yang besar bagi siswa. Hal ini karena siswa lebih merasa nyaman jika diberikan waktu untuk berpikir, semakin banyak waktu yang diberikan, semakin sedikit kesalahan yang mereka lakukan (Raba, 2017). Ahmed menyatakan bahwa TPS selain bertujuan meningkatkan hasil siswa juga untuk menstimulasi dan mengembangkan kemampuan berdiskusi mereka, TPS cocok untuk semua siswa di setiap jenjang pendidikan bahkan untuk siswa yang baru pertama kali menggunakan pembelajaran kooperatif (Hamdan, 2017).

Penelitian terdahulu menunjukan bahwa TPS dapat meningkatkan hasil belajar matematika siswa, diantaranya yaitu penelitian yang dilakukan oleh Diana (2018). Hasil penelitian menunjukkan bahwa terdapat peningkatan hasil belajar matematika dari kondisi awal, siklus I dan siklus II. Bukan hanya pada pembelajaran matematika saja, hasil penelitian Meiharty (2018) menunjukkan bahwa model pembelajaran TPS dapat meningkatkan hasil belajar IPS Siswa. Oleh sebab itu, penelitian ini bertujuan untuk meningkatkan hasil belajar matematika siswa melalui penerapan model pembelajaran think pair share pada kelas III SDN 009 Rambah Samo.

\section{METODE PENELITIAN}

Jenis penelitian yang digunakan yaitu Penelitian Tindakan Kelas (PTK). menurut Huda (2015) PTK merupakan pendekatan sistematis untuk memperbaiki praktik belajar mengajar. Sedangkan, Kunandar (2008) menyatakan bahwa penelitian tidakan kelas adalah suatu kegiatan ilmiah yang dilakukan oleh guru di kelasnya melalui tindakan merancang, melaksanakan, mengamati dan merefleksikan tindakan tersebut melalui beberapa siklus secara kolaboratif dan partisipatif yang bertujuan untuk memperbaiki dan meningkatkan mutu proses pembelajaran di kelasnya. Berdasarkan pendapat di atas, disimpulkan bahwa Penelitian Tindakan Kelas merupakan salah satu upaya yang dilakukan guru untuk mengatasi segala jenis permasalahan yang ada pada saat proses pembelajaran baik dalam lingkup ruang kelas maupun proses belajar di luar sekolah. Dengan Penelitian tindakan kelas guru dapat mengetahui kinerja dan hasil yang akan didapatkan serta meningkatkan kualitas guru dalam pembelajaran. Penelitian PTK dilakukan melalui proses yang dinamis dan komplementari yang terdiri dari empat tahap yaitu, (1) perencanaan (planning), (2) tindakan (action), (3) pengamatan (observation), (4) refleksi (reflection) (Kunandar, 2008). Berdasarkan tahapan tersebut berikut gambaran PTK yang akan dilaksanakan dalam penelitian ini. 


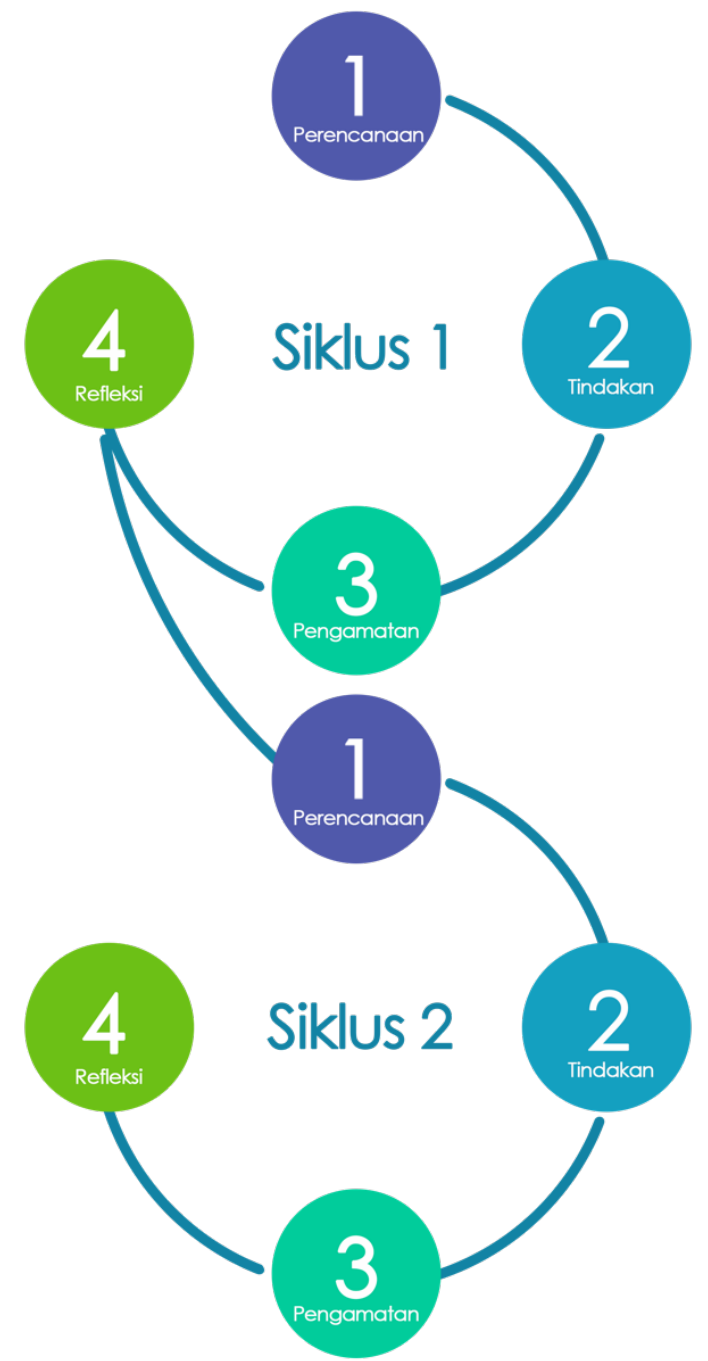

Gambar 1. Siklus PTK

Adapun rincian kegiatan PTK yang akan dilaksanakan yaitu:

1. Perencanaan

Pada tahap perencanaan ini guru menyusun RPP, Lembar Kerja Siswa (LKS), lembar observasi, serta soal untuk melihat pemahaman siswa terhadap materi yang diajarkan.

2. Tindakan

Pada tahap pelaksanaan, guru mengajar sesuai dengan RPP. Pada saat pembelajaran berlangsung, observer mengamati jalannya proses pembelajaran.

3. Pengamatan

Observasi dilakukan selama pengamatan tindakan sebagai upaya mengetahui jalannya pembelajaran. Kegiatan pada tahap ini juga merupakan kegiatan pengumpulan data. Pengumpulan data dilakukan dengan format observasi yang telah disusun.

4. Refleksi

Pada tahap ini guru berdiskusi dengan observer tentang pembelajaran yang telah dilakukan, baik kekurangan maupun ketercapaian pembelajaran. Hal ini 
digunakan untuk menyimpulkan data atau informasi yang dikumpulkan sebagai pertimbangan perencanaan pembelajaran pada siklus berikutnya.

Subjek penelitian ini adalah siswa kelas III SDN 009 Rambah Samo Tahun Pelajaran 2019/ 2020 yang berjumlah 23 orang. Penelitian ini dilaksanakan pada bulan September sampai dengan Oktober 2019. Instrumen yang digunakan dalam penelitian ini yaitu tes hasil belajar dan lembar pengamatan. Analisis data dilakukan dengan analisis deskriptif.

\section{HASIL DAN PEMBAHASAN}

Pelaksanaan PTK dilakukan secara kolaboratif antara guru kelas dengan observer (guru), yang membantu pelaksanaan observasi dan refleksi selama penelitian berlangsung, sehingga kegiatan penelitian ini dapat terkontrol untuk menjaga validitas hasil penelitian. Berikut rincian kegiatan PTK yang dilakukan per-siklus.

\section{Siklus I}

Siklus I dilaksanakan sebanyak 3 kali pertemuan dengan 2 kali pertemuan tatap muka dan 1 kali pertemuan untuk ulangan harian. Adapun tahapan yang dilaksanakan pada siklus I ini yaitu:

1. Perencanaan

Tahap perencanaan merupakan dimana peneliti menyiapkan segala kebutuhan yang diperlukan selama penelitian. Adapun yang dibutuhkan selama penelitian adalah perangkat pembelajaran dan instrumen pengumpul data. Perangkat pembelajaran terdiri dari silabus, RPP yang disusun untuk dua kali pertemuan, dan LKS yang dibuat untuk dua kali pertemuan. Instrumen pengumpul data yang digunakan adalah lembar pengamatan aktivitas guru dan siswa dan perangkat tes hasil belajar matematika untuk ulangan harian.

2. Pelaksanaan

Pelaksanaan tindakan dilakukan dengan menerapkan model pembelajaran TPS. Pembelajaran model pembelajaran TPS dilaksanakan sebanyak 2 kali pertemuan dengan materi mengenal alat yang digunakan untuk menimbang massa benda dan membaca timbangan suatu massa.

3. Pengamatan

Pengamatan dilakukan bersamaan dengan pelaksanaan proses pembelajaran. Observasi bertujuan untuk melihat aktivitas guru dan partisipasi siswa dalam pembelajaran. Observasi dilaksanakan oleh observer yang merupakan teman sejawat peneliti. Kegiatan yang dilakukan pada tahap ini adalah:

a. Mengamati partisipasi dan kreativitas siswa dalam pembelajaran.

b. Mengamati guru dalam aktivitas pembelajaran.

c. Mengamati pengelolaan kelas.

d. Mengamati respon siswa terhadap pembelajaran

Hasil pengamatan dijadikan bahan untuk tahapan kegiatan selanjutnya. 
4. Refleksi

Kegiatan refleksi dilakukan untuk mengevaluasi proses pembelajaran yang telah dilakukan. Refleksi dilakukan oleh peneliti bersama observer. Hasil refleksi digunakan untuk melakukan perbaikan siklus berikutnya. Beberapa hasil refleksi adalah sebagai berikut:

a. Umumnya kegiatan pembelajaran telah berjalan dengan baik.

b. Diskusi siswa pada tahap pair masih kurang maksimal, masih ada siswa yang mengerjakan hal lain.

c. Beberapa siswa hanya menyalin jawaban temannya.

d. Siswa masih malu-malu untuk mengemukakan pendapat pada tahapan share.

e. Saat mengerjakan tugas, masih banyak siswa yang tidak memanfaatkan waktu dengan baik.

Untuk meningkatkan partisipasi siswa dalam kelompok, maka pada siklus selanjutnya peneliti berinisiatif untuk memantau jalannya diskusi dan memberikan reward untuk kelompok yang aktif.

\section{Siklus II}

Siklus II juga dilaksanakan sebanyak 3 kali pertemuan dengan 2 kali pertemuan tatap muka dan 1 kali pertemuan untuk ulangan harian. Adapun tahapan yang dilaksanakan pada siklus II ini yaitu:

1. Perencanaan

Penyusunan perangkat pembelajaran dan instrument penelitian pada siklus II ini berdasarkan hasil refleksi pada siklus I. Adapun yang dibutuhkan selama penelitian adalah perangkat pembelajaran dan instrumen pengumpul data. Perangkat pembelajaran terdiri dari silabus, RPP yang disusun untuk dua kali pertemuan, dan LKS yang dibuat untuk dua kali pertemuan. Instrumen pengumpul data yang digunakan adalah lembar pengamatan aktivitas guru dan siswa dan perangkat tes hasil belajar matematika untuk ulangan harian.

2. Pelaksanaan

Pelaksanaan tindakan dilakukan dengan menerapkan model pembelajaran TPS. Pembelajaran model pembelajaran TPS dilaksanakan sebanyak 2 kali pertemuan dengan materi nilai satuan suatu massa dan cara menggunakan timbangan badan, serta membaca timbangan dalam kehidupan.

3. Pengamatan

Pengamatan dilakukan bersamaan dengan pelaksanaan proses pembelajaran. Observasi bertujuan untuk melihat aktivitas guru dan partisipasi siswa dalam pembelajaran. Observasi dilaksanakan oleh observer yang merupakan teman sejawat peneliti. Kegiatan yang dilakukan pada tahap ini adalah:

a. Mengamati partisipasi dan kreativitas siswa dalam pembelajaran.

b. Mengamati guru dalam aktivitas pembelajaran.

c. Mengamati pengelolaan kelas.

d. Mengamati respon siswa terhadap pembelajaran 
Hasil pengamatan dijadikan bahan untuk tahapan kegiatan selanjutnya.

4. Refleksi

Kegiatan refleksi dilakukan untuk mengevaluasi proses pembelajaran yang telah dilakukan. Refleksi dilakukan oleh peneliti bersama observer. Hasil refleksi digunakan untuk melakukan perbaikan siklus berikutnya. Beberapa hasil refleksi adalah sebagai berikut:

a. Kegiatan pembelajaran telah berjalan sesuai dengan RPP yang disusun.

b. Diskusi siswa pada tahap pair sudah berjalan dengan baik dan siswa terlibat aktif dalam berdiskusi.

c. Siswa sudah berani untuk mengemukakan pendapat pada tahapan share.

d. Siswa juga telah mengerjakan tugas sesuai dengan waktu yang ditentukan.

\section{Deskripsi dan Analisis Data Hasil Penelitian}

Pelaksanaan model pembelajaran TPS dari siklus I ke siklus II semakin membaik, hal ini terlihat dari hasil refleksi di setiap siklusnya. Pada siklus I siswa masih malu-malu untuk bertanya dan mengungkapkan pendapat namun pada siklus II hal ini sudah tidak ditemukan lagi, siswa sudah berani bertanya dan mengemukakan pendapat pada saat berdiskusi. Penerapan model pembelajaran TPS lebih menekankan kepada partisipasi siswa sehingga pembelajaran diharapkan lebih menarik. Siswa diberikan kesempatan untuk memikirkan dan memecahkan permasalahan matematika dengan pasangannya. Menurut Sagala (2009) pemecahan masalah dalam pembelajaran matematika merupakan proses yang penting, siswa dapat mencoba menemukan dan memecahkan permasalahan matematika. Oleh karena itu, siswa dapat termotivasi untuk bekerja keras dan berkreativitas. Guru dalam proses pembelajaran TPS hanya sebagai fasilitator dan motivator. Solusi permasalahan yang telah didiskusikan dengan pasangannya dipresentasikan di depan kelas. Setelah beberapa kelompok berbagi hasil diskusinya dengan kelompok lain, guru memberikan evaluasi terhadap hasil diskusi yang telah didiskusikan dan dipaparkan di depan kelas. Belajar yang berhasil jika dilalui berbagai macam aktivitas (Mustakim, 2009). Pembelajaran TPS tersebut mendorong siswa untuk beraktivitas bukan hanya fisik maupun mental.

Selain mampu meningkatkan kualitas proses pembelajaran, pembelajaran TPS juga mampu meningkatkan hasil belajar siswa dari sebelumnya. Hasil belajar siswa berdasarkan ulangan pada siklus I dan siklus II mengalami peningkatan. Hasil tersebut dapat dilihat pada tabel 1 berikut.

Tabel 1. Perbandingan Rata-Rata Hasil Belajar Matematika Siswa

\begin{tabular}{ccccc}
\hline Data & $\begin{array}{c}\text { Jumlah } \\
\text { Siswa }\end{array}$ & Rata-Rata & Peningkatan & $\begin{array}{c}\text { Persentase } \\
\text { Peningkatan }\end{array}$ \\
\hline Data Awal & 23 & 52,95 & - & - \\
\hline Siklus I & 23 & 69,86 & 16.91 & 31,94 \\
\hline Siklus II & 23 & 84,17 & 14.31 & 20,5 \\
\hline
\end{tabular}


Berdasarkan Tabel 1 di atas, terlihat bahwa rata-rata hasil belajar siswa sebelum diterapkannya pembelajaran TPS yaitu 52,95. Setelah dilaksanakan pembelajaran TPS pada siklus I rata-rata meningkat menjadi 69,86 dengan persentase peningkatan sebesar 31,94\%. Pertemuan dilanjutkan pada siklus II dan nilai rata-rata hasil belajar siswa juga mengalami peningkatan dengan rata-rata 84,17 dan persentase peningkatan sebesar 20,5\% dari siklus 1 .

Selain itu, ketuntasan individu dan klasikal juga dihitung dalam penelitian ini untuk mengetahui sejauh mana keberhasilan penerapan model pembelajaran TPS. Perbandingan ketuntasan individu dan klasikal pada data awal, siklus I, dan siklus II pada penerapan pembelajaran TPS dapat dilihat pada Tabel 2 berikut.

Tabel 2. Ketuntasan Individu dan Klasikal

\begin{tabular}{cccccc}
\hline \multirow{2}{*}{ Data } & Jumlah & \multicolumn{2}{c}{$\begin{array}{c}\text { Ketuntasan } \\
\text { Individu }\end{array}$} & \multicolumn{2}{c}{ Ketuntasan Klasikal } \\
\cline { 3 - 6 } & Siswa & Tuntas & $\begin{array}{c}\text { Tidak } \\
\text { Tuntas }\end{array}$ & $\begin{array}{c}\text { Persentase } \\
\text { Ketuntasan }\end{array}$ & Kategori \\
\hline Data Awal & 23 & 10 & 13 & $43,47 \%$ & $\mathrm{TT}$ \\
\hline Siklus I & 23 & 15 & 8 & $65,21 \%$ & $\mathrm{~T}$ \\
\hline Siklus II & 23 & 18 & 5 & $78,26 \%$ & $\mathrm{~T}$ \\
\hline
\end{tabular}

Berdasarkan tabel 2 terlihat bahwa ketuntasan individu mulai dari data awal sampai dengan siklus II mengalami peningkatan. Untuk lebih jelasnya, dapat dilihat pada diagram berikut.

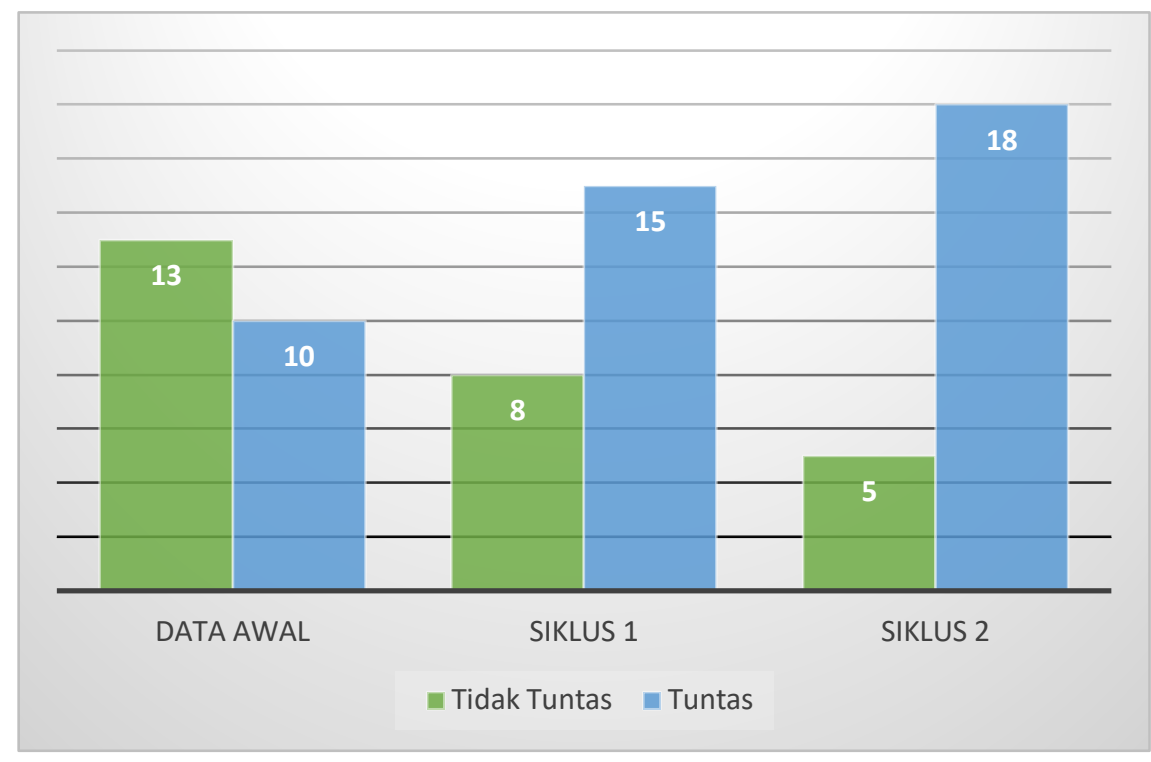

Gambar 2. Ketuntasan Individu

Hal yang sama juga terjadi pada persentase ketuntasan secara klasikal. Pada data awal ketuntasan secara klasikal siswa termasuk kategori Tidak Tuntas (TT) dikarenakan persentase ketuntasannya kurang dari 50\%. Namun, pada siklus I dan II persentase ketuntasan berada pada kategori Tuntas (T). Berdasarkan pemaparan dan fakta 
tersebut, terlihat bahwa penerapan pembelajaran TPS berhasil dalam meningkatkan hasil belajar matematika siswa.

\section{KESIMPULAN DAN SARAN}

Berdasarkan hasil analisis data dan pembahasan maka dapat disimpulkan bahwa penerapan pembelajaran TPS dapat meningkatkan hasil belajar matematika siswa SDN 009 Rambah Samo. Peningkatan hasil belajar matematika siswa terlihat dari peningkatan nilai rata-rata siswa, yaitu dari 52,95 pada data awal menjadi 69,86 pada siklus I dan 84,17 pada siklus II. Selain itu, ketuntasan individu maupun ketuntasan klasikal juga mengalami peningkatan. Pada saat data awal persentase ketuntasan siswa mencapai 43,47\% termasuk kategori tidak tuntas. Selanjutnya pada saat siklus I dan II meningkat menjadi $65,21 \%$ dan $78,26 \%$ dengan kategori tuntas.

berdasarkan hasil penelitian yang telah dilakukan, dapat diberikan beberapa saran sebagai berikut: 1) Guru hendaknya senantiasa memperbaiki proses pembelajaran di kelas untuk meningkatkan kemampuan siswa baik dari segi kognitif, afektif, maupun psikomotor. 2) Pembelajaran yang diterapkan hendaknya mengedepankan aktifitas belajar siswa, bukan terfokus pada guru. 3) Guru harus memiliki manajemen kelas yang baik agar dapat menciptakan suasana kondusif ketika belajar

\section{DAFTAR PUSTAKA}

Bamiro, A. O. 2015. Effects of Guided Discovery and Think-Pair-Share Strategies on Secondary School Students' Achievement in Chemistry. SAGE, 1-7.

Diana, A. L. (2018). Peningkatan Aktivitas Belajar Dan Hasil Belajar Melalui Model Pembelajaran Kooperatif Tipe Think, Pair, Share Pada Mata Pelajaran Matematika Siswa Kelas III Sekolah Dasar Negeri 02 Wonosari Gondangrejo Tahun Pelajaran 2016/ 2017. Karya IImiah Mahasiswa Progdi Pendidikan Guru Sekolah Dasar FKIP, 2(2).

Hamdan, R. K. A. 2017. The Effect of (Think-Pair-Share) Strategy on the Achievement of Third Grade Student in Sciences in the Educational District of Irbid. Journal of Education and Practice. 8(9), 88-95.

Huda, M. 2015. Penelitian Tindakan Kelas Teori dan Praktik. Yogyakarta: Pustaka Pelajar

Kunandar. 2008. Langkah Mudah Penelitian Tindakan Kelas sebagai Pengembangan Profesi Guru. Jakarta: Rajawali Press.

Kwok, A. P \& Lau, A. 2015. An Exploratory Study on Using the Think-Pair-Share Cooperative Learning Strategy. Journal of Mathematical Sciences. 2, 22-28.

Meiharty, F. 2018. Penerapan Model Pembelajaran Kooperatif Tipe Think Pair Share untuk Memperbaiki Proses Pembelajaran dan Meningkatkan Hasil Belajar IPS Siswa Kelas V SD Negeri 21 Balai Makam Kecamatan Mandau. Primary: Jurnal Pendidikan Guru Sekolah Dasar Fakultas Keguruan dan IImu Pendidikan Universitas Riau. 7(2), 312-320. 
Mustakim, Z. 2009. Metode dan Strategi Pembelajaran. Pekalongan: STAIN Press.

Raba, A. A. A. 2017. The Influence of Think-Pair-Share (TPS) on Improving Students' Oral Communication Skills in EFL Classrooms. Creative Education. 8, 12-23.

Sagala, S. 2009. Konsep dan Makna Pembelajaran. Bandung: Alfabeta.

Yamin, M., \& Ansari, B. I. (2009). Taktik mengembangkan kemampuan individual siswa. Jakarta: Gaung persada pers. 